\section{Iris Marion Young}

\section{Tributes from her colleagues in political theory at the University of Chicago}

Iris' written work has been very widely admired; she has obviously helped shape the field of democratic political theory; she has deeply influenced students. The discussion of this work will go on in books and articles until her ideas have been fully absorbed. Here I will say a little about my particular experience of her collegiality. I was Iris' junior colleague at Chicago for six years. I met Iris eight years ago this week, under a portico outside a large hotel like the one in which you are all gathered, not too long after I had first read Democracy and Difference and shortly before my first APSA paper presentation on, as it happened, deliberative democracy. I had no way of knowing then how directly and deeply she would affect my intellectual life. She was already for me a standard, even before I met her. But how that fact deepened over time is what I want to render here.

Our first meeting was accidental. I was exiting; she, entering. I caught a glimpse of her name tag and, overcome by my good fortune, waylaid her. "Prof. Young! I am so excited about your work!" I think I was that vague and direct in one breath. I had been expecting a monumental personality. She smiled broadly: "What are you working on?" I rushed to tell her and standing there in the portico, as her friend started to pull away a bit, she helped me with precise questions and some suggestions and then encouraged me to send her something. She was shorter than I. By a lot. My surprise at that fact in itself taught me something obvious about authority and its sources. She also gave me an important glimpse then of the true intellectual and political authority that comes from an egalitarian engagement with others.

This memory did not come back to me when I learned the sad news earlier this month. It has been with me quite persistently in these eight years, for in an instant she conveyed an openness and generosity of spirit that I have had scant occasion to observe in another. She had talked to this stranger as, in many conversations with her, I would eventually learn to think about that art and, thanks to Iris, gain a fuller sense of its value. She talked in this fashion consistentlyalways patient, always deliberate, always considerate, always curious, always questioning, always open to changing her mind, always by her example demanding that the rest of us also be so open. She talked this way in workshops, in the cof- fee shop, and, I would even say most importantly, in departmental meetings, some quite contentious. This allowed her to be a peace maker, without being a compromiser. In reading her work and watching her practice I learned how the unfathomably difficult and slow art of shaping our collective intellectual lives legitimately is done.

As my senior colleague, Iris, I think, did all the giving. Even in her careful stewardship of her self - with regard to her family and her music-she set a standard that I have not yet been able to live up to, though the gift of the model is immediately useful. The Saturday before her passing I phoned to chat about rescheduling a reading-group session she had had to cancel a week or so earlier. She and I and Bernard Harcourt were intending to meet to discuss Giorgio Agamben's Homo Sacer at Bernard's proposal. She did, she said, have to confess that she was having some difficulty getting a clear bead on the text (I do not report this as a description of her illness, for her mind was as sharp as ever). She continued, "But since so many people, and people I respect, seem to think there is something of value here, we'll just have to keep at it until we find it."

She set a standard for committed openness and proved how rich are the results of keeping to that standard. May I become a colleague worthy of her example.

Danielle Allen

I first read Iris's work in the early 1980s and soon thereafter met her when we both attended Habermas's Boston College lectures on the philosophical discourse of modernity. We became friends many years later, when we were both fellows at Princeton University's Center for Human Values.

I admired Iris for her intellectual breadth and rigor, for her ever-bright and welcoming self-confidence, and for her clear-eyed and insistent moral passion. I am grateful to have known her, and I shall miss her deeply.

\section{Robert Gooding-Williams}

On the eve of the deadline for collecting and assembling these tributes I still find it difficult to write about Iris. There's too much to say, but what I come back to again and again is this: she was one of those scholars who practiced-who lived, in the texture of her everyday life-what she preached; in her case, a systematic egalitarianism and opposition to hierarchy. I recall that I first saw her speak at a big lecture when I was in graduate school, where she was what I have now come to think of as her usual self-engaging, expressive, conversational, attentive to her audience. Later, I saw this same persona come out in her interactions with individuals at meetings and receptions; she was a great listener, and I have never seen anyone more comfortable with, or enthusiastic about, introducing herself to and talking with strangers, which she did with great warmth and sincerity. It's no surprise to find her writing about the rhetorical practice of "greeting" as part of an inclusive democratic politics.

Of course, that was not the only side of Iris. I recall that, at the Harvard lecture, some people in the crowd found her to be displeasingly radical-I think the problem was that she had suggested there was a racial dimension to welfare reform!- and I remember with some pleasure how, in response to one particularly snippy comment from the audience ("Do you really mean to say ... ?"), she set her jaw, narrowed her eyes a little, lowered her voice a half-step, and quite persuasively stood her ground. Similarly, if she thought you were engaging in sloppy reasoning or dodging a question, that same steeliness would come out. It was surely dumb luck that, in the seven years we were colleagues, I only really felt that steeliness directed at me once; and it was because - in a fit of anxiety-induced junior-faculty obsequiousness-I had just apologized to her because I worried that I might have stepped out of line or usurped her authority on some departmental matter. She set her jaw, furrowed her brow, lowered her voice a half-step, and said: "Promise me you will never apologize for anything like that again." The fierce eyes and furrowed brow, no less than the outstretched hand and the warm smile, were oriented toward equality.

Patchen Markell

Four years ago when we first became colleagues, I was of course already familiar with Iris Marion Young's scholarship. Justice and the Politics of Difference was and obviously will remain a landmark in moral and political philosophy. No one had so forcefully argued for sex- and identity-based justice claims, and had so impressively incorporated them into a progressive political vision still committed to equitable material redistribution. Political theory would never be the same.

At that point in time, however, I had no idea what a wonderful teacher, departmental citizen, and person Iris was. Iris's tireless dedication to her students set an incredibly high standard for the rest of us at Chicago. She was 
fiercely loyal to them but also unyieldingly demanding, never flinching from delivering hard facts when, for instance, her students submitted underdeveloped work or, despite their expectations to the contrary, they weren't yet ready for the job market. Her departmental citizenship was likewise exemplary: she brought tenacity and incorruptible judgment to issues seemingly far removed from her own areas of concern. I quickly learned that Iris's genuine commitment to the common good dictated that, regardless of the time and energy costs to herself and her research, all departmental concerns were her concerns as well.

Iris's generosity of spirit was especially evident on occasions when she fundamentally disagreed with colleagues: she always made it a point to convey both privately and publicly her sincere respect for them and to acknowledge the validity of their arguments - and do so without ever compromising her own intensely felt and thoroughly reasoned positions. In the aftermath of our only disagreement of real consequence, she grabbed my arm, looked me in the eyes, and whispered quietly but confidently: "these things can make departments and friendships stronger."

Iris was a curious and endearing mix of confidence and insecurity. As anyone who knew her is aware, Iris adopted an onward and upward approach to lifelike someone on a perpetual mountain hike. She was also possessed by a passion for justice that drove her to make unfashionable arguments and point out what are now called inconvenient truths. But for all of her hard-earned and richly deserved international fame, and despite the undaunted and undauntable face with which she confronted the world, on more than one occasion, I found myself struck and touched by her expressions of selfdoubt and vulnerability. The general resistance and, frankly, occasional scorn that met her unfashionable arguments, unrelenting truth-telling, and unconventional approaches to scholarship did not leave her completely unscarred. Once, when I suggested that she take the initiative on a particular issue in the department, she responded: “John, I'm not sure that all of our colleagues hold me in the same esteem that you do." Iris was quite aware that she had detractors, even at a university and in a department that pride themselves on supporting excellence in the quirky and the unorthodox.

Much as this disappointed her, she did not dwell on it or let it overshadow her life and or inhibit her vocations as scholar, activist, teacher, mentor, and friend. She confronted her illness in much the same way. Iris did not ignore or dis- count the pain and discomfort it caused her, or the fears it aroused in her; she spoke about all of these things openly but then inevitably moved on, setting out to accomplish whatever she could under the circumstances, always expanding the boundaries of what was conventionally expected. We haven't begun to fathom how much we'll miss her.

\section{John P. McCormick}

Iris's work was very important, but I won't discuss it here, for three reasons. There isn't room; I've agreed to write a paper on her work for a formal session at the APA; and the work is still alive.

Iris was my colleague, and I want to try to convey to you what an extraordinary colleague she was. Let me begin with my first meeting with her. In around 1995 I was in Frankfurt to lead a seminar for a budding women's studies program in the philosophy department. Iris had been there teaching for several weeks, so after the seminar we all went out to dinner. It quickly became clear to me that in that short time she had developed warm supportive relationships with the female faculty and graduate students, knew their projects, and was infusing them with an invaluable sort of hope and confidence. Then Iris proposed that we should all speak German. At that time I could read pretty well but was desperately bad at speaking. So was Iris. But that did not deter her. She was determined that we would not behave like visiting dignitaries, but would make ourselves vulnerable, and promote a more equal type of friendship, by stumbling and blundering around in our hosts' language. I would have been embarrassed to make so many errors, and I kept on being embarrassed as I did so. But Iris had the courage of true concern, as, with her characteristic warmth and directness, she said whatever she could and then stopped to inquire about the rest. She created a wonderful spirit in the group by that one gesture.

When I heard that Iris was coming to the University of Chicago, then, I already felt very happy for our graduate students, and it was indeed a happy era. Iris was in political science and I in philosophy, but we worked with a lot of the same students, and I came to know on a daily basis Iris's wonderful capacity for intellectual empathy. Many students wrote on topics on which Iris herself had written, but there were also many who came to Iris just because she was Iris, whether they thought she knew anything about their topic or not. One woman was working on the capabilities approach in the area of environmental policy-making. I went to the prospectus exam wondering whether Iris would really encourage such a project, which focused on a body of work in philosophy and economics that was rather distant from Iris's own work. Not that I thought she'd have any hostility to the project, I just didn't know whether she'd get inside it. I needn't have asked the question. Iris was totally inside the nature of the project, had her usual rigorous objections and suggestions, but also her characteristic maternal warmth that let the student know that she was going to be all right. Iris was a mother in the best sense, fostering development toward high ideals while conveying a sense of ultimate safety and support, something like unconditional love if there can be that in the relationship between professor and graduate student.

Whenever Iris was in a seminar or faculty discussion group, whenever we discussed drafts of work in progress, it was the same there too: always keen criticisms, some of which have been reshaping some of my work; but always the sense that underlying that was a huge reservoir of warmth and joie de vivre that embraced us both and the whole enterprise we were engaged in together. After her hospitalization in 2005, when her hair started to grow back and her weight gradually went up, it was a joy to witness the personality of Iris beginning to flourish anew, as her sheer delight in every part of our academic life, even the boring and terrible parts, shone in her eyes, and just the sight of her characteristic walk, as she approached, made everyone around her happier.

Once when Iris was in the hospital, in May 2005, she asked me to read a paper aloud for her at the APA. I was honored to do so, but I felt so keenly my notbeing-Iris, as I realized not only my utter inability to answer questions about her paper (which is not too surprising), but also my lack of certain Irisean features of connection with the audience, of warmth and that willingness to be vulnerable that I had seen so long ago in Frankfurt. Of the voice of Iris, which was silent only briefly, that time in 2005 .

\section{Martha Nussbaum}

Everyone knows that Iris was one of the most important and creative political theorists of the last quarter-century; she was also an amazing colleague and teacher. She had such generous curiosity about other people's views, and she always brought out the absolute best in others-in terms of their substantive arguments and in terms of their human characteristics. Of course Iris had passionate commitments to political ideals; she also lived those very same 
commitments, not least by treating other people, and competing ideas, not just with respect, but also with a kind of joy.

\section{Cass R. Sunstein}

Others can speak with more authority about Iris Marion Young as a scholar and teacher but I can testify whole-heartedly that she was a wonderful colleague. The congenial collegial collaboration of the distinguished theorist of the politics of difference and the scholar of Machiavelli, Locke, and Strauss may have surprised some observers - it may even have surprised the two of us. As soon as Iris arrived at Chicago we had lunch to discuss the state of political theory in the department and the university, the political theory workshop, and the Classics of Social and Political Thought common core sequence, and we hit it off at once. I was immediately won over by her openmindedness, enthusiasm, and solicitude for students and colleagues. Though I do not find academic administrative tasks uniformly enjoyable, I always found it a real pleasure to work with Iris whether on establishing and administering field exams in political theory, running our workshop and common core sequence, performing the duties of an ad hoc committee, or planning for faculty recruitment. She was contagiously cheerful even in trying circumstances. When she rewrote my prose, my pride of authorship gave way to gratitude for her straightforward improvements. She was always ready to do more than her share without a hint of self-righteousness, in a gracious way that inspired one to do likewise. She was a good citizen who cared deeply about the local as well as the global common good because she was a good person: fair-minded and good-hearted to the core. I can hardly believe she is gone and I know I will miss her terribly.

\section{Nathan Tarcov}

\section{Harmon Zeigler}

L. Harmon Zeigler died from a massive heart attack in Tacoma on July 31, 2006. He is survived by his wife of 50 years, Pat; his two children, Mike and Amanda; and three grandchildren, Ben, Zoe and Ruby.

Harmon was born in Savannah, Georgia on March 9, 1936. Among his earliest—and, for him, perhaps his proudest - achievements was playing for the Georgia Bulldogs, an athletic career that was, sadly, ended early by a knee injury. He received a B.A. from Emory University in 1957, an M.A. from the
University of Illinois, Champaign/ Urbana in 1958, and a Ph.D. also from Illinois in 1960 - the latter completed when he was only 24 . Following graduation, he took positions at Florida State University (1960-1961); at Emory University (1961-1963); and at the University of Georgia (1963-1964) before coming as an associate professor to the political science department and the Center for the Advanced Study of Educational Administration at the University of Oregon in 1964. He became a full professor of political science at the University of Oregon and director of the University's Center for the Educational Policy and Management in 1967. After 21 years at Oregon, he took an endowed chair at the University of Puget Sound.

Throughout his career Harmon held many visiting professorships, including at the University of Washington (1966), the University of Oslo (1972); the University of Sydney, Australia (1978) and the State University of New York, Stony Brook (1979).

He left a very substantial legacy of scholarship in political science. To several generations of political science undergraduates, he was surely best known for his very successful text with Tom Dye, The Irony of Democracy: An Uncommon Introduction to American Politics, whose first edition appeared in 1970 and whose $13^{\text {th }}$ edition appeared in 2005. The book's success derived in part, no doubt, from the clarity and grace of its writing, but most certainly also from the "uncommon" fact that, as a text, it not only provided systematic coverage of the major institutions of American democracy, but also that it argued a thesis - that government in the late-twentieth and twenty-first centuries is, contrary to myth, government by elites, not masses. Based firmly on contemporary scholarship, The Irony challenged students to rethink many of the assumptions about American government on which they had been raised.

His scholarly record was formidable. Writing alone and with various collaborators, he published more than 30 books and monographs and many articles, often in the discipline's leading journals. His major substantive focus was on state and local politics, on electoral behavior, and, in particular, on educational policy and politics; one recurring theme in the latter domain was the governance of American schools, and the politics of educational governance - a field that he substantially pioneered. But he also branched well beyond those topics, perhaps most notably undertaking a major comparative analysis of interest groups and conflict management in his Pluralism, Corporatism, and Confucianism: Political Associations and
Conflict Regulation in the United States, Europe and Taiwan; also, writing with Keith Pool, addressing the changing role of women in American elections in their Women, Public Opinion and Politics: The Changing Political Attitudes of American Women (Longman) and "The Diffusion of Feminist Ideology" in Political Behavior (1981). Harmon was pluralistic in methodological terms, but his openness to diverse theoretical perspectives in political science and neighboring disciplines was apparent to all his colleagues-he was endlessly curious about just what they were working on, even if remote from his own current interests - and the many people who met and talked with him at conferences.

Harmon was awarded research grants or fellowships from the Ford Foundation (1969); the John Simon Guggenheim Foundation (1969-1970); The National Institute of Education (1973-1976); The Earhart Foundation (1973-1974); Fulbright-Hays (to West Germany in 1977 and to Australia in 1978); the Pacific Cultural Foundation (1982); and the Spencer Foundation (1982). He served on many editorial boards and as a consultant for many journals and publishing companies. At the University of Oregon, he served on a wide range of departmental and university committees, in addition to being chair of the political science department from 1982-1985. Those of us who were in the department at that time remember his humor, wit, and charmwhich made department meetings events that (astonishingly!) were eagerly anticipated and, certainly, enjoyed. That humor, wit, and charm made him a wonderful friend and, with Pat, a no less wonderful host and dinner companion.

Harmon collaborated with a remarkable array of scholars-including (alphabetically) Alvin Boskoff, Mike Baer, T. L. Becker, Mick Boss, Tom R. Dye, L. A. Froman, Jr., John Grove, Michael Huelshoff, E. Kehoe, M. Kent Jennings, K. F. Johnson, Norman Luttbeg, Joseph Olexa, Wayne Peak, Keith Poole, J. Reisman, B. L. Smith, Harlan Strauss, T. L. Thorston, Harvey Tucker, Hendrik Van Dalen, and L. A. Wilson. Many of these were already leading scholars; others were Harmon's students who went on to important careers after graduation-in some cases including ongoing collaboration with Harmon himself.

Harmon Zeigler left a major intellectual legacy, but he also left many friends at Oregon and in the discipline more broadly, all of whom join his family in mourning his loss.

John Orbell University of Oregon 